\title{
EDITORIAL \\ ÉTICA NA PESQUISA DE ENFERMAGEM
}

\author{
Marcia Tereza Luz Lisboa
}

Ética é uma palavra de muitos significados. Ela está preocupada em como as pessoas devem agir e se relacionar com os outros. A ética não apenas descreve como as coisas são, mas também se preocupa com o estabelecimento de normas ou padrões para uma vida e conduta ideais. Ela se volta para as questões do bem e do mal, da conduta certa ou errada, do caráter ou das razões.

Segundo Boff, a ética vem do grego ethos e designa a morada humana. 0 ser humano separa uma parte do mundo para, moldando-a ao seu jeito, construir um abrigo protetor e permanente. A ética, como morada humana, não é algo pronto e construído de uma só vez. 0 ser humano está sempre tornando habitável a casa que construiu para si. Ético significa, portanto, tudo aquilo que ajuda a tornar melhor o ambiente para que seja uma morada saudável: materialmente sustentável, psicologicamente integrada e espiritualmente fecunda.

0 foco das nossas discussões éticas deslocou-se ultimamente do campo da prática, do exercício profissional, para o desenvolvimento ético de nossas pesquisas, situação muito devida à ampliação do domínio das enfermeiras sobre a prática de pesquisa e da expansão dos cursos de pós-graduação em enfermagem.

A Enfermagem já usa e discute assuntos referentes à ética e bioética, na abordagem dos dilemas no cotidiano da prática, dos princípios morais, da ética profissional, dos direitos e das obrigações no cuidado de saúde e dos direitos do paciente (direitos do deficiente físico, do deficiente mental, do paciente psiquiátrico, idoso etc). Faltava à profissão uma abordagem ética explícita de pesquisa. Não que nossas pesquisas estivessem sendo feitas sem ética, até porque esta é uma discussão que tem dez anos no trabalho de campo em pesquisa, no Brasil.

A ciência sempre guardou um lado sombrio sobre os processos que resultaram nas vacinas, descobertas terapêuticas e práticas medicamentosas, para citar algumas áreas típicas de pesquisa com seres humanos. Qual foi o preço (alto) dos seres humanos para contribuir para este desenvolvimento (des)necessário? Ao se estudar a história da ciência, defrontamo-nos com verdadeiras atrocidades realizadas em nome dela. Os experimentos com seres humanos expressam uma equação em cheque, aplicam uma medida de valor considerando na balança sofrimento versus ganho e risco de conseqüências desconhecidas versus recompensas das descobertas científicas.

Desde 1996, a área da saúde está sob influência da Resolução n. ${ }^{0}$ 196/96, do Conselho Nacional de Saúde, do Ministério da Saúde, que orienta sobre a pesquisa com seres humanos. Essa resolução incorpora, sob a ótica do indivíduo e das coletividades, os quatro referenciais básicos da bioética: autonomia, beneficência, não-maleficência, e justiça. Como um padrão da ética, a autonomia refere-se à independência de uma pessoa representando um acordo para se respeitar os direitos do próximo ao determinar o curso da ação. Através do Termo de Consentimento Livre e Esclarecido dos indivíduos-alvo de uma pesquisa, estamos tratando-os com dignidade, respeitando-os na sua autonomia e defendendo-os na sua vulnerabilidade. A beneficência refere-se a fazer ações positivas para ajudar outras pessoas. É a ponderação entre riscos e benefícios, tanto atuais como potenciais, individuais ou coletivos, o que leva o desenvolvimento de uma pesquisa a se comprometer com o máximo de benefícios e o mínimo de danos e riscos. A não-maleficência é o compromisso de não prejudicar, é a garantia de que danos previsíveis serão evitados. Por fim, a justiça tem a ver com a relevância social da pesquisa, as vantagens significativas para os sujeitos da pesquisa e a minimização do ônus para os 
sujeitos vulneráveis, o que garante a igual consideração dos interesses envolvidos, não perdendo o sentido de sua destinação sócio-humanitária.

A Resolução abrange também a criação de Comitê de Ética em Pesquisa. (CEP). Ele faz parte de uma longa trajetória histórica da humanidade para garantir os direitos humanos, a começar pelo Código de Nuremberg, um documento específico sobre ética na pesquisa em seres humanos que assegurou o respeito à autodeterminação do ser humano (autonomia). A partir dos Comitês de Ética, obtem-se o aval de um grupo consolidado designado para pensar, estudar, avaliar, orientar, e garantir que as nossas pesquisas estejam atendendo a todas as resoluções publicadas pelo Conselho Nacional de Saúde sobre o tema.

Os CEP foram criados atendendo a uma demanda das instituições por reconhecer os avanços científicos e tecnológicos, o aumento da consciência pública e a participação das enfermeiras no mundo da pesquisa com seres humanos. 0 Comitê de Ética em Pesquisa surge como um colegiado interdisciplinar e independente, que deverá cada vez mais existir nas instituições que realizam pesquisas envolvendo seres humanos, como no caso da Escola de Enfermagem Anna Nery e do Hospital Escola São Francisco de Assis, ambos da Universidade Federal do Rio de Janeiro. 0 CEP foi instituido para defender os interesses dos sujeitos da pesquisa na sua integridade e dignidade e para contribuir no desenvolvimento da pesquisa dentro dos padrões éticos estabelecidos.

0 CEP tem sido não somente responsável pela avaliação, mas também pelo acompanhamento dos aspectos éticos das pesquisas envolvendo seres humanos. Ele se apóia em todos os movimentos, diretrizes nacionais e internacionais que garantem o direito do ser humano. A missão, então, é salvaguardar os direitos e a dignidade dos sujeitos da pesquisa.

Por fim, ressalta-se que esta Revista, confirmando uma tendência geral da Enfermagem e da Saúde, ao solicitar de seus assinantes o parecer "Aprovado" de algum Comitê de Ética em Pesquisa para a pesquisa a ser publicada, contribui para a garantia de uma melhor qualidade ética de seus artigos.

\section{Referência}

Boff L. Ética da vida. Brasília: Letraviva, 1999. 241 p.

\section{Sobre a Autora}

Marcia Tereza Luz Lisboa

Professora Adjunta do Departamento de Enfermagem Fundamental e Coordenadora Adjunta de Pesquisa e Desenvolvimento da EEAN/UFRJ.

Coordenadora do Comitê de Ética em Pesquisa da EEAN e HESFA /UFRJ. 


\title{
EDITORIAL
}

\section{ETHICS IN THE NURSING RESEARCH}

\author{
Marcia Tereza Luz Lisboa
}

Ethics is a word of many meanings. It is worried on as the people must act and relate with each other. The ethics not only describe as the things are, but also it is worried about the establishment of norms or standards for an ideal life and behavior. It faces itself to questions of the good and the evil, of the right or wrong behavior, of the character or of the reasons.

According to Boff, the ethics come from the Greek word ethos and assign the human residence. The human being separates a part of the world for, molding it according them skill, to construct a protective and permanent shelter. The ethics, as human residence, is not something ready and constructed at once. The human being is always becoming habitable the house that constructed for themselves. Ethics means, therefore, everything what helps to become the environment better so that it is a healthful residence: materially sustainable, psychologically integrated and spiritually fruitful.

The focus of our ethical quarrels was dislocated lately from the field of the practical, of the professional exercise, for the ethical development of our research, situation that owes itself to the magnifying of the domain of the nurses on the practical of research and of the expansion of the after-graduation courses in nursing.

The Nursing already uses and argues referring subjects to the ethics and bioethics, in the approach of the daily practical dilemmas, of the moral principles, of the professional ethics, of the rights and of the obligations in the health care and of the rights of the patient (right of the physicist deficient, mental deficient, the psychiatric, aged patient etc). It was missing to the profession an explicit ethical approach to the research. Isn't means that our research was being made without ethics, furthermore this is a quarrel that is only ten years old in the work of field in research, in Brazil.

Science always kept a shady side on the processes that had resulted in vaccines, therapeutical discovered and medical practices, to cite some typical areas of research with human beings. Which was the price (high) of the human beings to contribute for this (un)necessary development? When we study the history of science, we confront ourselves with true atrocities carried through in name of it. The experiments with human beings express an equation in check, apply a measure of value considering in the scale suffering versus profit and risk of unknown consequences versus reward of the scientific discoveries.

Since 1996, the health area is under influence of the Resolution \#196/96, of the National Advice of Health, from the Ministry of Health, that guides on the research with human beings. This resolution incorporates, under the optics of the individual and of the collectives, the four basics referential of bioethics: autonomy, beneficence, not-slander, and justice. As a standard of the ethics, the autonomy mentions the independence of a person representing an agreement to respect the rights of the other when determining the course of the action. Through the Term of Free and Clarified Assent of the individual-target of one search, we are treating them with dignity, respecting them in their autonomy and defending them in their vulnerability. The beneficence is mentioned to make positive actions to help other people. It is the balance between risks and benefits, current and potential, individual or collective, what leads the development of a research to compromise to the maximum of benefits and the minimum of damages and risks. The not-slander is the commitment to not harm, is the guarantee of that previsible damages will be prevented. Finally, justice means the social relevance of the research, the significant advantages for the citizens of the research and the minimizations of the responsibility for the 
vulnerable citizens, what it guarantees the equal consideration of the involved interests, not losing the direction of its destination partner-humanitarian.

The Resolution also encloses the creation of Committee of Ethics in Research. (CEP). It is part of a long historical trajectory of the humanity to guarantee the human rights, starting on the Code of Nuremberg, a specific document on ethics in the research in human beings that assures the respect to the self-determination of the human being (autonomy). From the Committees of Ethics, the endorsement of a consolidated group is gotten assigned to think, to study, to evaluate, to guide, and to guarantee that our research is taking care of to all the resolutions published for the National Advice of Health on the subject.

The CEP had been created to take care of the demand of the institutions for recognizing the scientific and technological advances, the increase of the public conscience and the participation of the nurses in the world of the research with human beings. The Committee of Ethics in Research appears as an interdisciplinary and independent collegiate, that must exist even more in the institutions that carry through research involving human beings, as in the case of the Anna Nery School of Nursing and of the Hospital School San Francisco de Assis, both from the Federal University of Rio de Janeiro. The CEP was instituted to defend the interests of the citizens of the research in their integrity and dignity and to contribute to the development of the research according to the established ethical standards.

The CEP has been not only responsible for the evaluation, but also for the accompaniment of the ethical aspects of the research involving human beings. It bases itself in every movement, national and international lines of direction that guarantee the right of the human being. The mission, then, is to safeguard the rights and the dignity of the citizens of the research.

Finally, it stands out that this Journal, confirming a general trend of the Nursing and of the Health, when requesting to their subscribers the "Approved" seeming of some Committee of Ethics in Research for the search be published, contributes for the guarantee of a better ethical quality of their articles.

\section{Reference}

Boff L. Ética da vida. Brasília: Letraviva, 1999. 241 p.

\section{About the author}

Marcia Tereza Luz Lisboa

Assistant Professor of the Fundamental Nursing Department and

Assistant Coordinator of Research and Development of the EEAN/UFRJ.

Coordinator of the Ethics in Reasearch Comitee of the EEAN and HESFA/UFRJ. 


\section{EDITORIAL}

\section{ÉTICA EN LA INVESTIGACIÓN DE ENFERMERÍA}

Marcia Tereza Luz Lisboa

Ética es una palabra de muchos significados. Ella está preocupada en como las personas deben actuar y relacionarse con los otros. La ética no solo describe como son las cosas, pero también se preocupa con el estabelecimiento de normas o patrones para una vida y conducta ideales. Ella se vuelve para las cuestiones del bien y del mal, de la conducta cierta o errada, del carácter o de las razones.

Conforme Boff, la palabra ética viene del grego ethos y designa la morada humana. El ser humano aparta una porción del mundo para, moldeándola a sua manera, construir un abrigo protector y permanente. La ética, como morada humana, no es algo acabado y construido solo de una vez. El ser humano está siempre haciendo habitable la casa que construyó para si. Ético, por lo tanto, significa todo aquello que ayuda a mejorar el ambiente para que sea una morada saludable: materialmente sustentable, psicológicamente integrada y espiritualmente fecunda.

El foco de nuestras discusiones éticas se dislocó últimamente del campo de la práctica, del ejercicio profesional, para el desarrollo ético de nuestras investigaciones, lo que se debe mucho a la ampliación del dominio de las enfermeras sobre la práctica de pesquisa y de la expansión de los cursos de postgrado en enfermería.

La Enfermería ya usa y discute asuntos referentes a la ética y a la bioética, en el enfoque de los dilemas en el cotidiano de la práctica, de los principios morales, de la ética profesional, de los derechos y de las obligaciones en el cuidado de salud y de los derechos del paciente (derechos del deficiente físico, del deficiente mental, del paciente psiquiátrico, del anciano, etc). Faltaba a la profesión un enfoque ético explícito de la investigación. No que nuestras investigaciones tengan sido hechas sin ética, hasta porque esta es una discusión que tiene diez años en en el trabajo de campo en investigación, en el Brasil.

La ciencia siempre resguardó un lado sombroso sobre los procesos que resultaron en las vacunas, en los descubrimientos terapéuticos y en las prácticas medicamentosas, eso para citar algunas áreas típicas de investigación con seres humanos. ¿Cuál fue el precio (alto) de los seres humanos para contribuir para este desenvolvimento (des)necesario? Al estudiarse la historia de la ciencia, somos afrontados por verdaderas atrocidades perpetradas en nombre de ella. Los experimentos con seres humanos expressan una ecuación dilemática, ellos aplican una medida de valor considerando, en la balanza, sufrimiento versus ventaja y riesgo de consecuencias desconocidas versus recompensas de los descubrimientos científicos.

Desde 1996, el área de la salud está bajo la influencia de la Resolución 196/96, del Consejo Nacional de Salud, del Ministerio de la Salud - Brasil, que orienta la investigación con seres humanos. Esa Resolución incorpora, bajo la óptica del individuo y de las colectividades, los cuatro referenciales básicos de la bioética: autonomía, beneficencia, no maleficencia y justicia. Como un patrón de la ética, la autonomía se refiere a la independencia de una persona, lo que representa un acuerdo para respetarse los derechos del otro al determinar el curso de la acción. A través del Termo de Consetimento Libre y Esclarecido de los sujetos de una investigación, estamos tratándolos con dignidad, respetándolos en su autonomía y defendiéndolos en us vulnerabilidad. La beneficencia dice respecto a la práctica de acciones positivas para aydar otras personas. Ella es la ponderación entre riesgos y beneficios, tanto actuales cuanto potenciales, individuales o colectivos, lo que lleva el desarrollo de una investigación a comprometerse con el máximo de beneficios y el mínimo de daños y riesgos. La no-maleficencia es el compromiso de no perjudicar, es la garantía de que daños previsibles serán evitados. Por fin, la justicia tiene a ver con la relevancia social de la pesquisa, con las ventajas significativas 
para los sujetos de la investigación y con la minimización del encargo para sujetos vulnerables, lo que garantiza la consideración igual de los intereses implicados, no perdiendo el sentido de su destinación social y humanitaria.

La Resolución abarca también la creación del Comité de Ética en Investigación (CEP). Él hace parte de un largo camino histórico de la humanidad para asegurar los derechos humanos, a comenzar por el Código de Nuremberg, un documento específico sobre ética en la investigación con seres humanos que aseguró el respeto a la autodeterminación del ser humano (autonomía). A partir de los Comités de Ética, se obtiene al aval de un grupo consolidado designado para pensar, estudiar, evaluar, orientar y asegurar que nuestras investigaciones estean considerando todas las resoluciones publicadas por el Consejo Nacional de Salud acerca del tema.

Los CEP fueron creados atendiendo a una demanda de las instituciones por reconocer los avances científicos y tecnológicos, el aumento de la conciencia pública y la participación de las enfermeras en el mundo de la investigación con seres humanos. El Comité de Ética en Investigación surge como un colegiado interdisciplinario e independiente, lo cual deberá existir cada vez más en las instituciones que realizan pesquisas con seres humanos, como la Escuela de Enfermería Anna Nery y el Hospital Escuela São Francisco de Assis, ambos de la Universidad Federal de Rio de Janeiro. El CEP fue instituido para defender los intereses de los sujetos de la investigación en su integridad y dignidad y para contribuir en el desarrollo de la investigación conforme los patrones éticos estabelecidos.

El CEP es responsable no solo por la evaluación, pero también por el acompañamiento de los aspectos éticos de las investigaciones envolviendo seres humanos. Él se apoya en todos los movimientos, directrices nacionales e internacionales que garantizan el derecho del ser humano. La misión, entonces, es salvaguardar los derechos y la diginidad de los sujetos de la investigación.

Finalmente, se resalta que esta Revista, confirmando una tendencia general de la Enfermería y de la Salud, al solicitar de sus subscriptores el dictamen "Aprobado" de algun Comité de Ética en Investigación para que su trabajo pueda ser publicado, contribuye para la garantía de una calidad ética mejor de sua artículos.

\section{Referencia}

Boff L. Ética da vida. Brasília: Letraviva, 1999. 241 p.

\section{Sobre la Autora}

\section{Marcia Tereza Luz Lisboa}

Profesora Adjunta del Departamiento de Enfermería Fundamental y

Coordinadora Adjunta de Investigación y Desarrollo de la EEAN/UFRJ.

Coordinadora del Comité de Ética en Investigación de la EEAN e HESFA /UFRJ. 